\title{
ANALISIS WATER BALANCING PRIMARY LOOP CHILLER SYSTEM TERHADAP COP (COEFFICIENT OF PERFORMANCE)
}

\author{
Komarudin ${ }^{1}$, Ida El Methelina Manik ${ }^{2}$ \\ Program Studi Teknik Mesin, Institut Sains dan Teknologi Nasional, Jakarta ${ }^{1} 2$ \\ email $^{1}$ : komarudin.mt@gmail.com
}

\begin{abstract}
Water is one of the major media for heat transfer process in the cooling system. The size of the flow rate of water entering the system will affect the overall cooling. Analysis of water balancing primary loop chiller system against COP (Coefficient Of Performance) is based on the observation the performance of the chiller system during operational with temperature of chilled water produced that not able to achieve the desired criteria when demand for chilled water increasing. After analysis conducted, it is known that decreasing efficiency of cooling system caused by uncontrolled water flow rate into the system. After water balancing is done, the flow rate of the water coming into the system (evaporator) can be controlled by using the balancing valve so that the flow rate increased from $16.07 \times 10^{-3} \mathrm{~m}^{3} / \mathrm{s}$ to $52.70 \times 10^{-3} \mathrm{~m}^{3} / \mathrm{s}$, resulting in increased chiller COP value system from 2.4 to 4.1 .
\end{abstract}

Keywords: water balancing, Coefficient of Performance, evaporator, balancing valve

\section{PENDAHULUAN}

Air dingin telah menjadi media utama untuk perpindahan / transfer panas yang digunakan dalam suatu bangunan dengan berbagai metode sistem pendingin. Menyediakan air dingin dari suatu sistem yang berlokasi sama dengan bangunan yang memerlukan air dingin tersebut dianggap sebagai salah satu cara untuk menjadikan energi menjadi lebih efisien karena biaya perawatan dan operasionalnya akan menjadi lebih kecil jika dibandingkan dengan penyediaan air dingin dari luar lokasi pengguna.

Chiller system dan cooling tower merupakan kontributor terbesar untuk menghasilkan air pendingin. Pada saat kebutuhan akan air pendingin meningkat, evaporator dalam chiller system berperan sangat penting guna menghasilkan air dingin sesuai dengan kebutuhan. Ketika laju aliran air yang masuk ke dalam mesin pendingin kecil atau kurang dari kapasitas desain yang seharusnya, sehingga air pendingin yang diperoleh tidak akan mampu menjangkau titik pengguna air dingin tersebut secara keseluruhan.

Di sisi lain banyaknya aliran air yang masuk kedalam media pendingin juga dapat mengakibatkan mesin pendingin tidak mampu menanggung beban pendinginan sehingga air yang keluar dari mesin pendingin tidak dapat mencapai kriteria yang diinginkan. Akibatnya efisiensi dari mesin pendingin menjadi menurun.

\section{TINJAUAN PUSTAKA}

\section{Pengertian Umum Sistem Pendingin}

Sistem pendinginan adalah suatu rangkaian yang awalnya digunakan untuk mengatasi terjadinya over heating (panas yang berlebihan) pada mesin agar mesin bisa bekerja secara stabil, menjaga temperatur pada ruangan tertentu.

Chiller atau mesin refrigerasi merupakan suatu peralatan yang biasanya digunakan untuk menghasilkan media pendingin dengan mengkonsumsi energi secara langsung berupa energi listrik, thermal atau mekanis, untuk menghasilkan air dingin (chilled water) dan membuang kalor panas ke udara (atmosfir) melalui sebuah menara pendingin (cooling tower) atau kondensor. Air dingin yang dihasilkan selanjutnya didistribusikan ke mesin penukar kalor yaitu FCU (Fan Coil Unit) atau AHU (Air Handling Unit).

Dalam sistem pengkondisian udara, chiller berfungsi memproduksi air sejuk yang akan didistribusikan ke FCU dan AHU. Sedangkan untuk proses produksi, air dingin yang dihasilkan oleh chiller digunakan sebagai pendingin pada heat exchanger.

\section{Siklus Standar Kompresi Uap}

Siklus standar kompresi uap adalah siklus mesin pendingin yang menggunakan proses penguapan dalam menyerap panas dengan menggunakan media pendingin refrigerant atau Freon serta peralatan utama yang meliputi: 
kompressor, kondensor, katup ekspansi / pipa kapiler dan evaporator.

Siklus kompresi uap merupakan daur kompresi yang terpenting. Pada daur ini uap ditekan, kemudian diembunkan menjadi cairan, lalu tekanannya diturunkan agar cairan, tersebut dapat menguap kembali

Daur kompresi uap standar terdiri dari 4 komponen utama, yaitu evaporator, kompresor, kondensor dan katub ekspansi.

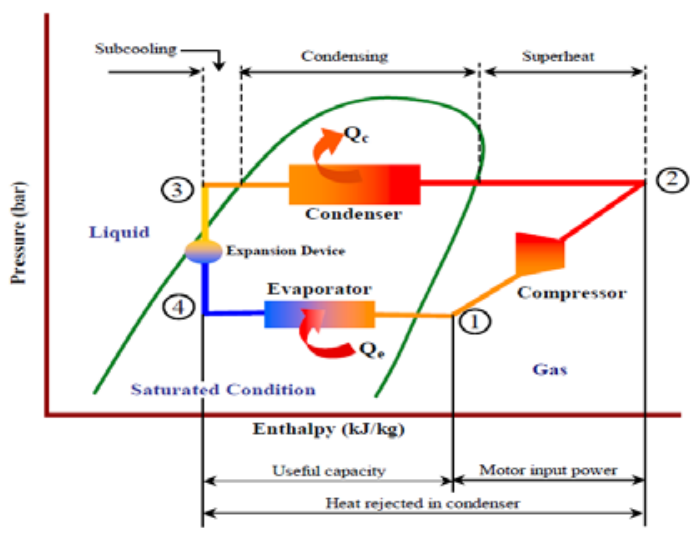

Gambar 1. Skema komponen utama mesin pendingin siklus kompresi uap dengan P-h diagram.

\section{Proses Kompresi 1 - 2:}

Kompresi adiabatis reversibel: merupakan kompresi kering (uap dalam keadaan superheated) yang berlangsung didalam kompresor, dari tekanan evaporator menuju tekanan kompresor. Refrigerant dihisap kompresor dan meninggalkan evaporator dalam wujud uap jenuh dengan kondisi temperatur dan tekanan rendah, kemudian oleh kompresor uap tersebut dinaikan tekanannya menjadi uap dengan tekanan yang lebih tinggi (tekanan kondensor).

Kompresi diperlukan untuk menaikkan temperatur refrigerant, sehingga temperatur refrigerant didalam kondensor lebih tinggi dari pada temperatur lingkungan. Maka perpindahan panas dari refrigerant ke lingkungan dapat terjadi. Dengan demikian proses 1-2 tersebut adalah kompresi isentropik disepanjang garis entropi konstan, mulai dari uap jenuh hingga tekanan pengembunan. Maka besar kerja kompresi dapat dihitung dengan rumus:

Dimana:

$$
\mathbf{W}_{\mathbf{k}}=\dot{\mathbf{m}} \cdot\left(\mathbf{h}_{\mathbf{2}}-\mathbf{h}_{\mathbf{1}}\right)
$$

$\mathrm{W}_{\mathrm{k}}$ : Kerja kompresi $(\mathrm{kW})$

$\dot{\mathrm{m}}$ : Laju aliran massa refrigerant $(\mathrm{kg} / \mathrm{s})$

$\mathrm{h}_{1}$ : Entalphy refrigerant saat masuk kompresor $(\mathrm{kJ} / \mathrm{kg})$

$\mathrm{h}_{2}$ : Entalphy refrigerant saat keluar kompresor $(\mathrm{kJ} / \mathrm{kg})$

\section{Proses Kondensasi 2 - 3:}

Setelah mengalami proses kompresi, refrigeran berada dalam fase panas lanjut dengan tekanan dan temperatur tinggi. Untuk merubah wujudnya menjadi cair, kalor harus dilepaskan kelingkungan. Proses ini terjadi pada alat penukar kalor yang disebut kondensor. Refrigerant mengalir melalui kondensor dan pada sisi lain dialirkan fluida pendingin (air atau udara) dengan temperatur yang lebih rendah dari temperatur refrigerant.

Kalor akan berpindah dari refrigerant ke fluida pendingin dan sebagai akibat refrigerant mengalami penurunan temperatur dari kondisi uap panas lanjut menuju kondisi uap jenuh. Selanjutnya mengembun menjadi fase cair dan keluar dari kondensor berfase cair jenuh.

Kesimpulannya proses kondensasi ini adalah proses pengeluaran kalor secara isobarik reversible pada kondensor. Dengan kata lain proses 2-3 tersebut merupakan penurunan panas lanjut dan pengembunan dengan tekanan tetap, yang merupakan garis lurus mendatar pada diagram tekanan entalpi. Besar kalor yang dilepaskan oleh kondensor dapat ditulis dengan persamaan:

$$
\begin{gathered}
\mathbf{Q c}=\dot{\mathbf{m}} \cdot \mathbf{q C} \\
\mathbf{q c}=\mathbf{h}_{2}-\mathbf{h}_{3} \\
\mathbf{Q c}=\dot{\mathbf{m}}_{\text {ref॰ }}\left(\mathbf{h}_{2}-\mathbf{h}_{3}\right)
\end{gathered}
$$

Dimana:

Qc : Kalor yang dilepas di Condenser $(\mathrm{kW})$

$\dot{\mathrm{m}}_{\text {ref }}$ : Laju aliran massa refrigerant $(\mathrm{kg} / \mathrm{s})$

qc : Kerja yang dilakukan kondenser $(\mathrm{kJ} / \mathrm{kg})$

$\mathrm{h}_{2} \quad$ : Entalphy refrigerant keluar kondenser $(\mathrm{kJ} / \mathrm{kg})$

$\mathrm{h}_{3} \quad$ : Entalphy refrigerant masuk kondenser $(\mathrm{kJ} / \mathrm{kg})$

\section{Proses Ekspansi 3 - 4:}

Refrigerant dalam wujud cair jenuh mengalir melalui alat ekspansi. Refrigerant mengalami proses ekspansi pada entalpi konstan terjadi pada katup ekspansi dan berlangsung secara tak reversibel. Selanjutnya refrigerant keluar dari alat ekspansi berwujud campuran uap-cair pada tekanan dan temperatur sama dengan tekanan evavorator. Proses 3-4 berlangsung pada entalpi tetap, karena tegak lurus pada bagan.

\section{Proses Evaporasi 4 - 1:}

Refrigerant dalam fasa campuran uap-cair, mengalir melalui sebuah penukar kalor yang disebut evaporator. Pada tekanan evaporator, titik didih refrigerant haruslah lebih rendah daripada temperatur lingkungan (media kerja atau media yang didinginkan), sehingga dapat terjadi perpindahan panas dari media kerja ke dalam refrigerant. 
Kemudian refrigerant yang masih berwujud cair menguap di dalam evaporator dan selanjutnya refrigerant meninggalkan evaporator dalam fasa uap jenuh. Proses penguapan tersebut adalah proses pemasukan kalor secara isobarik reversibel pada evaporator yang menyebabkan refrigerant menguap menjadi uap jenuh.

Proses 4-1 merupakan garis lurus mendatar karena aliran refrigerant melalui evaporator dianggap tekanan tetap.

$$
\begin{gathered}
\mathbf{Q}_{\mathbf{e}}=\dot{\mathbf{m}} . \mathbf{E R} \\
\mathbf{E R}=\mathbf{h}_{1}-\mathbf{h}_{4} \\
\mathbf{Q e}=\dot{\mathbf{m}}_{\text {ref. }}\left(\mathbf{h}_{1}-\mathbf{h}_{4}\right)
\end{gathered}
$$

Dimana:

Qe : Kalor yang dilepas di evaporator $(\mathrm{kW})$

$\dot{\mathrm{m}}_{\mathrm{ref}}:$ Laju aliran massa refrigerant $(\mathrm{kg} / \mathrm{s})$

$\mathrm{h}_{1}$ : Entalphy refrigerant keluar evaporator $(\mathrm{kJ} / \mathrm{kg})$

$\mathrm{h}_{4} \quad$ : Entalphy refrigerant masuk evaporator $(\mathrm{kJ} / \mathrm{kg})$

\section{Macam - macam Sistem Pendingin \\ Sistem Pendinginan AC Central}

Merupakan sistem pendingin ruangan yang dikontrol dari satu titik atau tempat dan di distribusikan secara terpusat ke seluruh isi gedung dengan kapasitas yang sesuai dengan ukuran ruangan dan isinya dengan menggunakan saluran udara/ducting.

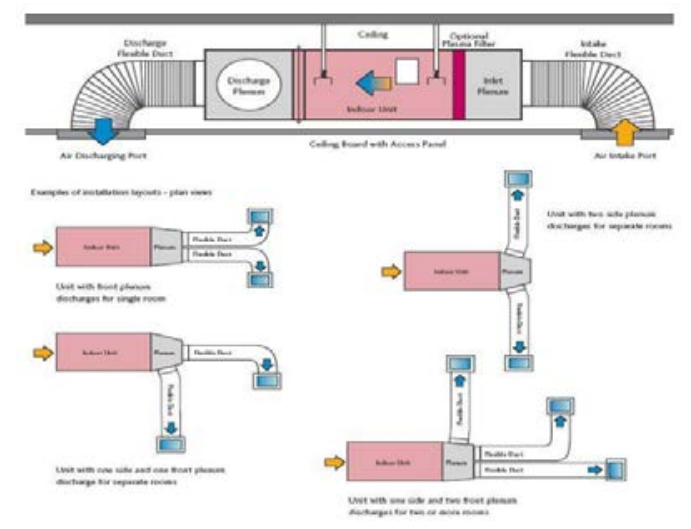

Gambar 2 AC Sentral

Istilah Sistem AC Sentral (Central) diperuntukkan untuk instalasi AC di satu gedung yang tidak memiliki pengatur suhu sendiri-sendiri (misalnya per ruang).

Secara garis besar pendinginan sentral memiliki beberapa komponen utama yaitu unit pendingin atau Chiller, Unit pengatur udara atau Air Handling Unit (AHU), Cooling Tower, system pemipaan, system saluran udara atau ducting dan system control \& kelistrikan.

\section{Sistem Pendinginan AC Split}

Prinsip kerja AC Split maupun pada mesin pendingin yaitu menyerap panas udara di dalam ruangan yang didinginkan, kemudian melepaskan panas keluar ruangan. AC split merupakan seperangkat alat yang mampu mengkondisikan suhu ruangan sesuai yang kita inginkan, terutama mengkondisikan suhu ruangan menjadi lebih rendah suhunya dibanding suhu lingkungan sekitarnya.

Pada AC split, udara yang berada di dalam ruangan terhisap kemudian disirkulasikan secara terus menerus oleh blower (pada indoor unit) melalui sirip evaporator yang mempunyai suhu yang lebih dingin dari suhu ruangan. Udara yang diserap dari dalam ruangan selanjutnya bersirkulasi di dalam evaporator. Panas yang diserap oleh bahan pendingin/refrigerant di dalam evaporator kemudian dilepaskan ke luar ruangan ketika aliran refrigerant melewati kondensor (unit outdoor).

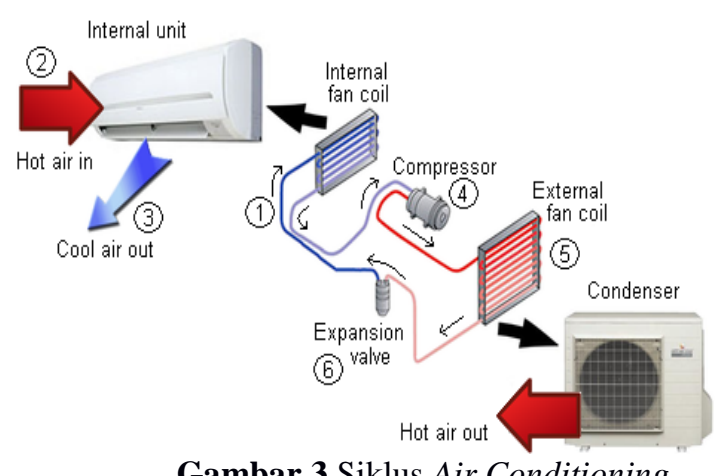

Gambar 3 Siklus Air Conditioning

\section{Cooling Tower Unit}

Unit ini berfungsi sebagai sebagai pendingin unit condenser pada unit chiller dengan media yang digunakan adalah air. Sistem kerja cooling tower dapat di jelaskan sebagai berikut: condenser di unit chiller akan memiliki temperatur dan tekanan yang tinggi akibat tekanan kerja dari kompresor, sehingga diperlukan media pendingin untuk merubah fase refrigerant di condenser tersebut.

Sistem pendinginan dilakukan dengan menggunakan media air yang disirkulasikan oleh pompa ke unit cooling tower. Air yang disirkulasikan tersebut akan membawa kalor dari condenser untuk kemudian di lepaskan kalornya ke udara di cooling tower, sehingga air akan mengalami penurunan temperatur dan akan disirkulasikan kembali ke unit condenser. Unit cooling tower sendiri terdiri dari : satu unit casing cooling tower, motor blower, basin dan water filler atau jika diartikan menjadi siripsirip pendingin air. 


\section{Refrigerant}

Refrigerant adalah fluida kerja yang bersirkulasi dalam siklus refrigerasi. Refrigerant merupakan komponen terpenting siklus refrigerasi karena refrigerant yang menimbulkan efek pendinginan dan pemanasan pada mesin refrigerasi. ASHRAE (2005) mendefinisikan refrigerant sebagai fluida kerja di dalam mesin refrigerasi, pengkondisian udara, dan sistem pompa kalor. Refrigerant menyerap panas dari satu lokasi dan membuangnya ke lokasi yang lain, biasanya melalui mekanisme evaporasi dan kondensasi.

\section{Refrigerant yang digunakan (R-123)}

Refrigerant R-123 (HCFC-123) merupakan calon terbaik untuk menggantikan refrigerant R-11 (CFC-11) dengan pertimbangan bahan R-123 yang ramah lingkungan. Pada tekanan rendah dalam centrifugal chillers, R-123 memberikan efisiensi yang sangat baik dibandingkan dengan refrigerant lainnya. Selain itu keuntungan R-123 yaitu rendahnya biaya operasional secara keseluruhan terhadap peralatan baru.

Tabel 1. Spesifikasi CFC-11 \& HCFC-123

\begin{tabular}{|l|l|l|}
\hline Spesifikasi & CFC-ll & HCFC - 123 \\
\hline Boilling Point, ${ }^{\circ} \mathrm{C}(\mathrm{C} F)$ & $24(74.9)$ & $27.85(82.0)$ \\
\hline Flammability & - & - \\
\hline Ozone Depletion Potential & 1.0 & 0.02 \\
\hline Global Wraming Potential (100 yr. ITH) & 4600 & 120 \\
\hline Exposure Limit, ppm(viv) & $1.000 \mathrm{TLV}$ & $50 \mathrm{AEL}$ \\
\hline
\end{tabular}

\section{Dasar - dasar Perhitungan Unjuk Kerja Mesin Pendingin}

Dasar-dasar perhitungan unjuk kerja mesin pendingin siklus kompresi uap standar berlandaskan pada diagram hubungan temperatur (T) dengan entropi (s) dan tekanan (P) dengan enthalpi (h) untuk siklus kompresi uap standar.

\section{Efek Refrigerasi (ER)}

Efek refrigerasi (ER) adalah kalor yang diterima oleh sistem dari lingkungan melalui evaporator per satuan laju massa refrigerant. Efek refrigerasi merupakan parameter penting, karena merupakan efek yang berguna dan diinginkan dari suatu sistem mesin pendingin. Dari gambar 4, dapat dilihat bahwa efek refrigerasi ini berlangsung pada proses dari 4 ke 1.

Semakin besar efek refrigerasi suatu sistim refrigerasi, maka kinerja sistem makin baik. Besarnya efek refrigerasi tersebut yaitu:

$$
E R=h_{1}-h_{4}(\mathbf{k J} / \mathbf{k g})
$$

Dimana:

$\mathrm{h}_{1}$ : Enthalpi refrigerant yang keluar evaporator $(\mathrm{kJ} / \mathrm{kg})$

$\mathrm{h}_{4}$ : Enthalpi refrigerant yang masuk evaporator $(\mathrm{kJ} / \mathrm{kg})$

\section{Laju Aliran Massa Refrigerant}

Laju aliran massa refrigerant dalam suatu sistem menggambarkan banyak nya aliran massa refrigerant tiap satuan waktu.

$$
\dot{\mathrm{m}}_{\mathrm{ref}}=\frac{\text { Kapasitas Pendinginan (QE) }}{\text { Efek Refrigerasi }(E R)}
$$

Dimana:

$\mathrm{Q}_{\mathrm{e}} \quad$ : Beban pendinginan (Watt)

ER : Efek refrigerasi $(\mathrm{kJ} / \mathrm{kg})$

\section{Kerja Kompresi $\left(\mathbf{W}_{\mathrm{k}}\right)$}

Besarnya kerja kompresi (Wk) sama dengan selisih enthalpi uap refrigerant yang keluar kompresor dengan enthalpi uap refrigerant yang masuk ke kompresor pada proses $1-2$.

$$
\mathbf{W}_{\mathbf{k}}=\dot{\mathbf{m}}_{\mathrm{ref} \cdot}\left(\mathbf{h}_{2}-\mathbf{h}_{1}\right)(\mathbf{k J} / \mathrm{s})
$$

Dimana:

$\mathrm{h}_{1}$ : Enthalpi uap refrigerant pada sisi inlet kompresor $(\mathrm{kJ} / \mathrm{kg})$

$\mathrm{h}_{2}$ : Enthalpi uap refrigerant pada sisi outlet kompresor $(\mathrm{kJ} / \mathrm{kg})$

Hubungan tersebut diturunkan dari persamaan energi dalam keadaan tunak (steady flow energy equation) yaitu: $\mathrm{q}+\mathrm{h}_{1}=\mathrm{h}_{2}+\mathrm{W}_{\mathrm{k}}$ pada proses kompresi adiabatik reversibel dengan perubahan energi kinetik dan energi potensial diabaikan. Perbedaan entalpinya merupakan besaran negatif yang menunjukkan bahwa kerja diberikan kepada sistem.

\section{Unjuk Kerja (COP)}

Menurut Indartono (2006), unjuk kerja atau yang lebih dikenal dengan koefisien performansi $(\mathrm{COP}=$ Coefficient Of Performance $)$ merupakan perbandingan antara kapasitas refrigerasi (TR) dengan daya (Pk) yang dibutuhkan untuk menggerakkan kompresor. Untuk satu-satuan massa refrigerant maka unjuk kerja dapat didefinisikan sebagai perbandingan antara efek refrigerasi (ER) system dengan kerja (Wk) yang dibutuhkan untuk mengkompresi refrigerant di kompresor. Semakin besar nilai unjuk kerja (COP) semakin baik kinerja sistem refrigerasi itu. Unjuk kerja (COP) merupakan besaran tanpa dimensi. Prestasi mesin refrigerasi 
dapat diketahui dengan menggunakan persamaan berikut:

$$
\mathrm{COP}=\frac{E R}{W_{K}}=\frac{h_{1}-h_{4}}{\mathrm{~m} \cdot\left(h_{2}-h_{1}\right)}
$$

Dimana:

$$
\begin{array}{ll}
\text { COP } & \text { : Coefficient of Performance } \\
\text { ER } & : \text { Efek refrigerasi }(\mathrm{kJ} / \mathrm{kg}) \\
\mathrm{W}_{\mathrm{k}} & : \text { Kerja kompresi }(\mathrm{kJ} / \mathrm{kg})
\end{array}
$$

Unjuk kerja (COP) adalah besarnya energi yang berguna, yaitu efek refrigerasi dibagi dengan kerja yang diperlukan sistem (kerja kompresi). Unjuk kerja ini identik dengan efisiensi pada motor bakar. Kalau efisiensi biasanya memiliki nilai lebih kecil dari 1 sedangkan unjuk kerja biasanya lebih besar dari 1.

\section{Water Balancing System}

Sebuah distribusi air sistem pendingin dikatakan seimbang (balance) adalah ketika aliran di seluruh sistem sesuai dengan desain sistem untuk tingkat aliran yang dibutuhkan. Adapun cara untuk memperoleh sistem yang seimbang yaitu dengan menambahkan peralatan keseimbangan.

Beberapa keuntungan dari penerapan balancing yang tepat yaitu mengurangi kebisingan, getaran dan umpan balik yang diciptakan oleh mesin selama dalam kondisi beroperasi serta menjamin laju aliran yang tepat dan efisien untuk meningkatkan kinerja sistem.

\section{Prinsip Kerja Balancing Valve}

Balancing valve adalah sebuah katub atau perangkat hidrolik yang memungkinkan untuk mengatur laju aliran media (air) yang melewati sebuah sistem. Pengaturan laju aliran air yang melewati dilakukan oleh sebuah bola obtuator (1), yang dioperasikan oleh control stem (2). Laju aliran yang mengalir diatur oleh flow meter (3) pada by-pass circuit yang terletak pada valve body, yang dapat dimatikan selama fungsi normal. Nilai aliran ditunjukkan dengan bola logam (4) yang begeser dalam kotakan transparan (5) ditandai dengan skala ukuran (6).

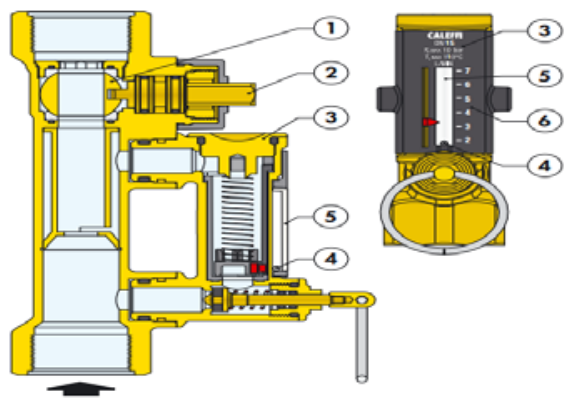

Gambar 4. Komponen Balancing Valve

\section{METODOLOGI PENELITIAN \\ Metode Penelitian}

Penelitian ini dilakukan berdasarkan diagram alir penelitian berikut:

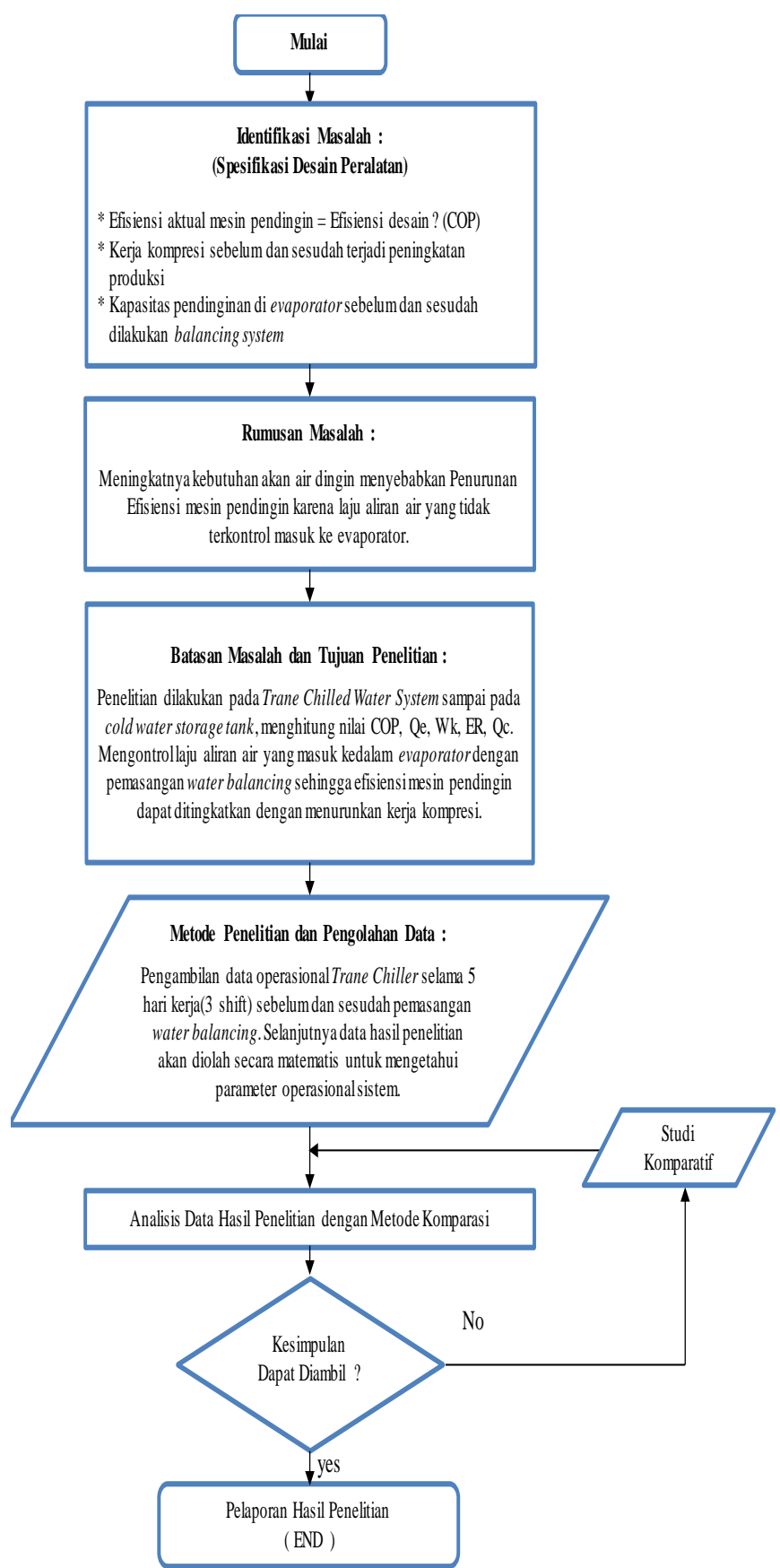

Gambar 5. Diagram alir proses penelitian.

\section{Peralatan yang Digunakan}

Penelitian dilakukan terhadap mesin Trane Chiller yang beroperasi untuk liquid plant dengan type CVHF 1070 menggunakan refrigeran HCFC123. Chilled water dari chiller system saat ini dipergunakan untuk memfasilitasi operasional FC \& HC plant, yang terdiri dari 2 mesin pendingin kapasitas 400TR (Trane) dan 300TR (York), akan tetapi yang akan dibahas pada skripsi ini hanya akan membahas satu mesin pendingin yaitu mesin trane 
chiller. Chiller system ini terdiri dari pompa chilled water dan pompa kondensor, cooling tower (air dari cooling tower sebagai media pendingin untuk air compressor kedua unit chiller), serta 2 buffer tank (cold well dan hot well).

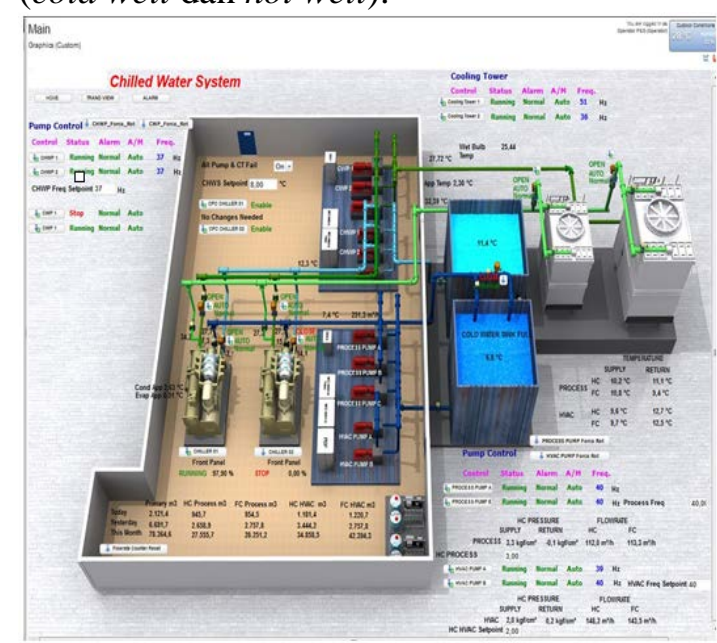

Gambar 6. Trane chiller system desain

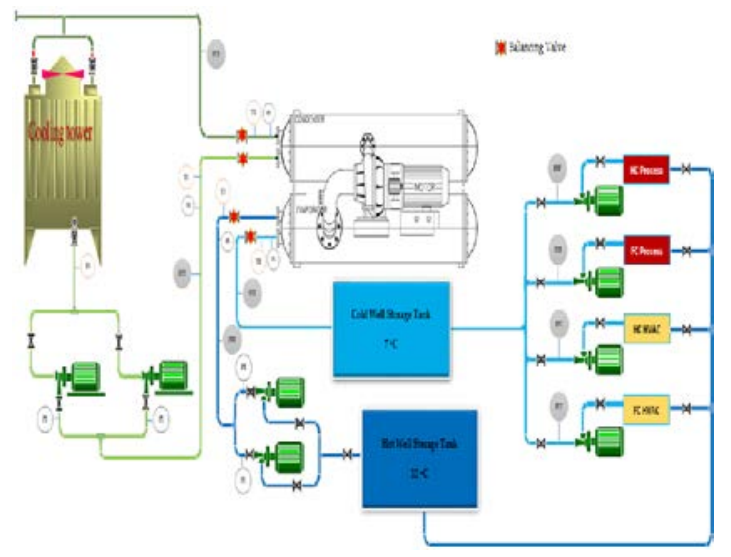

Gambar 7. Chilled water system balancing line diagram

\section{Balancing Flow Rate Adjustment}

Laju aliran yang masuk melalui balancing valve dapat disesuaikan dengan melalukan langkah langkah berikut:

a. Dengan bantuan dari indicator (1), tandai aliran sesuai dengan referensi tingkat dimana katub harus di atur.

b. Gunakan cincin (2) untuk membuka obtuator yang menutup dari aliran media dalam flow meter (3) dibawah kondisi normal operasional.

c. Tahan katub obtuator tetap terbuka, gunakan kunci pas pada control stem (4) untuk mengatur laju aliran. Hal ini ditunjukkan dengan bola logam (5) yang bergerak dalam kotak transparan (6), tandai skala aliran yang masuk dalam liter/menit.

d. Setelah menyelesaikan balancing, lepaskan cincin dari flow meter obtuator, pegas akan secara otomatis akan kembali ke posisi tertutup.
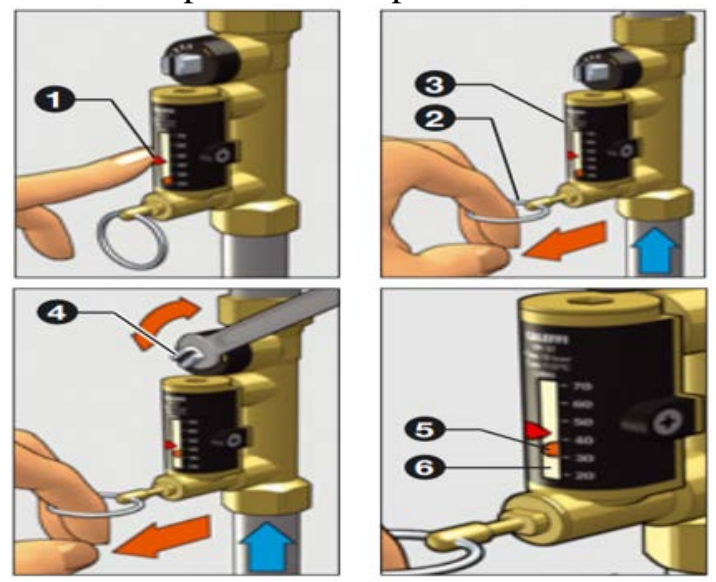

Gambar 8. Prosedur Flow rate Adjustment

Meningkatkan nilai COP mesin pendingin dengan metode water balancing dilakukan dengan mengatur besar kecilnya laju aliran air yang masuk ke dalam sistem. Dengan memasukkan nilai COP yang ingin dicapai sesuai dengan sistem desain maka laju aliran air yang masuk ke dalam sistem dapat dihitung melalui persamaan:

$$
\begin{gathered}
\operatorname{COP}=\frac{Q_{c}}{Q_{e}}=\frac{\left(h_{2}-h_{3}\right)}{\left(h_{1}-h_{4}\right)} \\
\mathbf{Q}=\dot{\mathbf{m}}_{\text {air }} \cdot \mathbf{C}_{\mathbf{p}} \cdot \Delta \mathbf{T}
\end{gathered}
$$

Jika nilai $\Delta \mathrm{T}$, kalor jenis air serta besarnya beban yang ditanggung oleh sistem telah diketahui berdasarkan sistem desain, maka laju aliran massa air yang masuk kedalam sistem dapat dihitung melalui persamaan:

$$
\dot{\mathbf{m}}_{\text {air }}=\frac{Q}{C_{p} \cdot \Delta t}
$$

Dimana:

$\mathrm{Q}_{\mathrm{c}}$ Kalor yang dilepas di kondenser $(\mathrm{kW})$

$\mathrm{Q}_{\mathrm{e}}$ : Kalor yang dilepas di evaporator $(\mathrm{kW})$

$\dot{\mathrm{m}}_{\text {air }}$ : Laju aliran massa air $(\mathrm{kg} / \mathrm{s})$

$\mathrm{C}_{\mathrm{p}}$ : kalor jenis air $\left(\mathrm{kJ} / \mathrm{kg}^{\circ} \mathrm{C}\right)$

$\Delta \mathrm{T}: \mathrm{T}^{-\mathrm{T}_{\mathrm{o}}}=$ perubahan suhu $\left({ }^{\circ} \mathrm{C}\right)$

T: Suhu mula-mula zat $\left({ }^{\circ} \mathrm{C}\right)$

$\mathrm{T}_{\mathrm{o}}$ : Suhu akhir zat $\left({ }^{\circ} \mathrm{C}\right)$

\section{Prosedur Penelitian \& Pengambilan Data \\ Persiapan Water Balancing Prosedur}

a. Pastikan level air di cooling tower dan storage tank mencukupi.

b. Periksa balancing valve, pastikan dapat beroperasi dengan baik.

c. Semua valve, flow meter dan temperatur/pressure indikator terpasang 
dengan benar, mudah diakses dan berfungsi.

d. Periksa dan atur setiap parameter operasional sesuai dengan persyaratan desain.

\section{Prosedur Balancing}

a. Nyalakan pompa chiller dan pompa cooling tower. Check pressure pompa ketika air masuk ke sistem sesuai dengan desain.

b. Pastikan tidak ada udara yang masih terperangkap dalam sistem, release udara yang terperangkap dengan air fan.

c. Check flow air di kondensor dan evaporator.

d. Nyalakan chiller dari HMI.

e. Atur kontrol valve untuk mengisi kondensor. Sistem diisi dengan air sesuai dengan level yang tepat dan katub pengatur tekanan di setting sesuai dengan yang dibutuhkan.

f. Check tekanan operasional pompa.

g. Periksa temperatur air dingin keluar dari evaporator (chilled water leaving temperature) dan return temperature (inlet) pada chiller sistem $\left(\Delta \mathrm{T}_{\text {desain }}=5\right.$ $\left.{ }^{\circ} \mathrm{C}\right)$.

h. Selanjutnya lakukan balancing proses untuk menyeimbangkan pendinginan air di evaporator dan kondensor.

i. Atur bukaan balancing valve inlet dan outlet (evaporator dan kondensor) untuk mencapai target $\Delta \mathrm{T}_{\text {desain }}$.

j. Catat dan periksa parameter operasional pada masing - masing komponen pendingin, seperti:

- penurunan tekanan pada masing masing komponen pendingin (evaporator dan kondensor)

- Pembacaan flow meter dan load chilled water system (Running Load Ampere).

\section{Prosedur Verifikasi Balancing Performa}

a. $\Delta \mathrm{T}$ desain tercapai $5{ }^{\circ} \mathrm{C}$ maksimal untuk evaporator, dan $5{ }^{\circ} \mathrm{C}$ minimal untuk kondensor.

b. Pressure dan flow air dingin tidak melebihi persyaratan minimum dan maksimum desain.

c. Periksa semua perbedaan dan kegagalan yang terjadi. Pastikan telah diperbaiki sebelum memulai pengambilan data.

d. Pastikan sistem dapat beroperasi secara otomatis selama 24 jam.

\section{Spesifikasi Data}

Pengambilan data hasil penelitian dilakukan selama 5 hari kerja (pagi, sore dan malam). Berikut data pengukuran hasil penelitian yang dilakukan.

\section{Operasional Desain Data}

Operasional desain data merupakan data spesifikasi peralatan berdasarkan desain aktual yang dimiliki oleh peralatan yang dikeluarkan oleh manufacturing dengan beberapa adjustment terhadap parameter operasional sesuai dengan aktual instalasi peralatan di PT. SJK Indonesia.

Tabel 3.1 Operasional desain data Evaporator \& Condensor

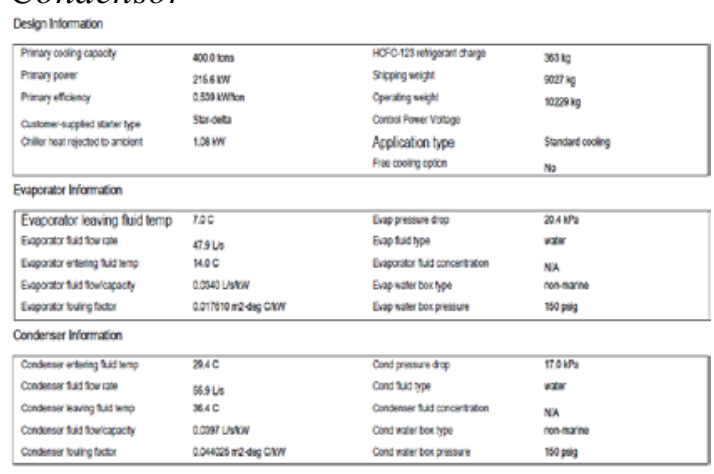

\section{Data Penelitian Sebelum Water Balancing}

Tabel 3.2 Data penelitian sebelum water balancing.

\begin{tabular}{|c|c|c|c|c|c|c|c|}
\hline \multirow{2}{*}{ Day } & $\left(\mathrm{T}_{1}\right)$ & $\left(\mathrm{h}_{1}\right)$ & $\left(\mathrm{T}_{2}\right)$ & $\left(\mathrm{h}_{2}\right)$ & $\left(\mathrm{T}_{3}\right)$ & $\left(\mathrm{l}_{3-4}\right)$ & $Q_{e}$ \\
\hline & ${ }^{0} \mathrm{C}$ & $\mathrm{kJ} / \mathrm{kg}$ & ${ }^{\circ} \mathrm{C}$ & $\mathrm{kJ} / \mathrm{kg}$ & ${ }^{\circ} \mathrm{C}$ & $\mathrm{kJ} / \mathrm{kg}$ & $\mathrm{kJ} / \mathrm{s}$ \\
\hline 1 & 8.0 & 384.6 & 41.4 & 405.2 & 38.0 & 166.3 & 917.9 \\
\hline 2 & 8.1 & 384.7 & 41.0 & 404.9 & 39.0 & 165.9 & 917.0 \\
\hline 3 & 8.1 & 384.6 & 41.4 & 405.2 & 38.5 & 166.1 & 1014.7 \\
\hline 4 & 8.3 & 384.8 & 41.1 & 405.0 & 37.7 & 166.4 & 1023.9 \\
\hline 5 & 8.1 & 384.6 & 40.8 & 404.8 & 37.3 & 166.6 & 1037.0 \\
\hline
\end{tabular}

\section{Data Penelitian Setelah Water Balancing}

Tabel 3.3 Data penelitian setelah water balancing.

\begin{tabular}{|c|c|c|c|c|c|c|}
\hline \multirow{2}{*}{ Day } & $\mathbf{( T}_{\mathbf{1}} \mathbf{)}$ & $\left.\mathbf{( h}_{\mathbf{1}}\right)$ & $\mathbf{( T}_{\mathbf{2}} \mathbf{)}$ & $\left.\mathbf{( h}_{\mathbf{2}}\right)$ & $\mathbf{( T}_{\mathbf{3}} \mathbf{)}$ & $\left.\mathbf{( h}_{\mathbf{3}-4}\right)$ \\
\cline { 2 - 7 } & ${ }^{\mathbf{0}} \mathbf{C}$ & $\mathbf{k J} / \mathbf{k g}$ & ${ }^{0} \mathbf{C}$ & $\mathbf{k J} / \mathbf{k g}$ & ${ }^{{ }^{0}} \mathbf{C}$ & $\mathbf{k J} / \mathbf{k g}$ \\
\hline 1 & 6.5 & 383.7 & 40.7 & 404.7 & 33.7 & 168.1 \\
\hline 2 & 6.5 & 383.7 & 41.2 & 405.1 & 34.7 & 167.7 \\
\hline 3 & 6.3 & 383.6 & 40.8 & 404.8 & 33.7 & 168.1 \\
\hline 4 & 6.9 & 383.9 & 40.9 & 404.9 & 33.5 & 168.2 \\
\hline 5 & 6.9 & 383.9 & 40.8 & 404.8 & 33.6 & 168.1 \\
\hline
\end{tabular}

\section{Pengolahan \& Perhitungan Data Penelitian Perhitungan Data Penelitian Sebelum Water Balancing}

Berdasarkan data penelitian sebelum water balancing dilakukan, diperoleh beberapa data sebagai berikut:

$\mathrm{T}_{1}=8{ }^{\circ} \mathrm{C} ; \mathrm{h}_{1}=384.6 \mathrm{~kJ} / \mathrm{kg} ; \mathrm{T}_{2}=41.4{ }^{\circ} \mathrm{C}$;

$\mathrm{h}_{2}=405.2 \mathrm{~kJ} / \mathrm{kg}$

$\mathrm{T}_{3}=38^{\circ} \mathrm{C} ; \mathrm{h}_{3}=\mathrm{h}_{4}=166.3 \mathrm{~kJ} / \mathrm{kg}$

Kapasitas Pendinginan $(\mathrm{Qe})=917.9 \mathrm{~kJ} / \mathrm{s}$

Efek Refrigerasi (ER) 


$$
\begin{aligned}
\mathrm{ER} & =\mathrm{h}_{1}-\mathrm{h}_{4} \\
& =384.6 \mathrm{~kJ} / \mathrm{kg}-166.3 \mathrm{~kJ} / \mathrm{kg} \\
& =218.3 \mathrm{~kJ} / \mathrm{kg}
\end{aligned}
$$

$$
\begin{aligned}
& \text { Laju Aliran Massa Refrigerant }\left(\dot{\mathbf{m}}_{\text {ref }}\right) \\
& \dot{\mathrm{m}}_{\text {ref }}=\mathrm{Qe} / \mathrm{ER} \\
& \dot{\mathrm{m}}_{\text {ref }}=(917.9 \mathrm{~kJ} / \mathrm{s}) /(218.3 \mathrm{~kJ} / \mathrm{kg}) \\
& \dot{\mathrm{m}}_{\text {ref }} \quad=4.2 \mathrm{~kg} / \mathrm{s}
\end{aligned}
$$

Kerja Kompresi yang dilakukan oleh sistem (Wk)

$$
\begin{aligned}
\mathrm{W}_{\mathrm{k}} & =\dot{\mathrm{m}}_{\text {ref. }}\left(\mathrm{h}_{2}-\mathrm{h}_{1}\right) \\
& =4.2 \mathrm{~kg} / \mathrm{s} .(405.2 \mathrm{~kJ} / \mathrm{kg}-384.6 \mathrm{~kJ} / \mathrm{kg}) \\
& =86.8 \mathrm{~kJ} / \mathrm{s}
\end{aligned}
$$

\section{Kalor yang dilepaskan oleh kondensor (Qc)}

$\mathrm{QC}=\dot{\mathrm{m}}_{\text {ref. }}(\mathrm{h} 2-\mathrm{h} 3)$

$$
\begin{aligned}
& =4.2 \mathrm{~kg} / \mathrm{s} .(405.2 \mathrm{~kJ} / \mathrm{kg}-166.3 \mathrm{~kJ} / \mathrm{kg}) \\
& =1004.7 \mathrm{~kJ} / \mathrm{s}
\end{aligned}
$$

$$
\begin{aligned}
& \text { COP (Coefficient Of Performance) } \\
& \text { COP }=\frac{\frac{E R}{W_{K}}=\frac{h_{1}-h_{4}}{\mathrm{~m} .\left(h_{2}-h_{1}\right)}}{\text { COP }}=\frac{384.6 \frac{\mathrm{kJ}}{\mathrm{kg}}-166.3 \frac{\mathrm{kJ}}{\mathrm{kg}}}{4.2 \frac{\mathrm{kg}}{\mathrm{g}} \cdot\left(405.2 \frac{\mathrm{kJ}}{\mathrm{kg}}-384.6 \frac{\mathrm{kJ}}{\mathrm{kg}}\right)} \\
& \text { COP }=2.5
\end{aligned}
$$

Dengan menggunakan rumus yang sama seperti diatas berikut diperoleh tabel hasil perhitungan data penelitian untuk keseluruhan data sebelum water balancing:

Tabel 3.4: Hasil perhitungan data sebelum water balancing

\begin{tabular}{|c|c|c|c|c|}
\hline $\mathbf{E R}$ & $\dot{\mathbf{m}}_{\text {ref }}$ & $\mathbf{W}_{\mathbf{k}}$ & $\mathbf{Q}_{\mathbf{c}}$ & \multirow{2}{*}{$\mathbf{C O P}$} \\
\cline { 1 - 4 } $\mathbf{k J} / \mathbf{k g}$ & $\mathbf{k g} / \mathbf{s}$ & $\mathbf{k J} / \mathbf{s}$ & $\mathbf{k J} / \mathbf{s}$ & \\
\hline 218.3 & 4.2 & 86.8 & 1004.7 & 2.5 \\
\hline 218.8 & 4.2 & 85.0 & 1002.0 & 2.6 \\
\hline 218.5 & 4.6 & 95.7 & 1110.4 & 2.3 \\
\hline 218.3 & 4.7 & 94.9 & 1118.7 & 2.3 \\
\hline 218.1 & 4.8 & 95.6 & 1132.6 & 2.3 \\
\hline
\end{tabular}

\section{Perhitungan Data Penelitian Setelah Water Balancing}

Berdasarkan data setelah water balancing dilakukan, diperoleh beberapa data sebagai berikut:

$\mathrm{T}_{1}=6.5{ }^{\circ} \mathrm{C} ; \mathrm{h}_{1}=383.7 \mathrm{~kJ} / \mathrm{kg} ; \mathrm{T}_{2}=40.4{ }^{\circ} \mathrm{C} ; \mathrm{h}_{2}$ $=404.5 \mathrm{~kJ} / \mathrm{kg}$

$\mathrm{T}_{3}=34.8{ }^{\circ} \mathrm{C} ; \mathrm{h}_{3}=\mathrm{h}_{4}=167.7 \mathrm{~kJ} / \mathrm{kg}$

Kapasitas Pendinginan (Qe) $=554.7 \mathrm{~kJ} / \mathrm{s}$

$$
=216.0 \mathrm{~kJ} / \mathrm{kg}
$$

\begin{tabular}{|c|c|c|c|c|}
\hline ER & $\dot{\mathbf{m}}_{\text {ref }}$ & $\mathbf{W}_{\mathbf{k}}$ & $\mathbf{Q}_{\mathrm{c}}$ & \multirow{2}{*}{ COP } \\
\hline $\mathrm{kJ} / \mathrm{kg}$ & $\mathrm{kg} / \mathrm{s}$ & $\mathrm{kJ} / \mathrm{s}$ & $\mathrm{kJ} / \mathrm{s}$ & \\
\hline 216.0 & 2.6 & 53.4 & 608.1 & 4.0 \\
\hline 216.1 & 2.5 & 52.8 & 587.3 & 4.1 \\
\hline 215.5 & 2.4 & 51.7 & 577.1 & 4.2 \\
\hline 215.7 & 2.5 & 52.4 & 591.7 & 4.1 \\
\hline 215.8 & 2.5 & 52.9 & 600.0 & 4.1 \\
\hline
\end{tabular}

$$
\begin{aligned}
& \text { Laju Aliran Massa Refrigerant ( } \dot{\mathbf{m}}_{\text {ref }} \text { ) } \\
& \text { Kapasitas Pendinginan(Qe) } \\
& \dot{\mathrm{m}}_{\mathrm{ref}}=\text { EfekRefrigenasi }(E R) \\
& \dot{\mathrm{m}}_{\mathrm{ref}}=\frac{554.7 \mathrm{~kJ} / \mathrm{s}}{216.0 \mathrm{~kJ} / \mathrm{kg}} \\
& \dot{\mathrm{m}}_{\text {ref }}=2.6 \mathrm{~kg} / \mathrm{s}
\end{aligned}
$$

Kerja Kompresi yang dilakukan oleh sistem $\left(\mathbf{W}_{\mathrm{k}}\right)$

$\mathrm{W}_{\mathrm{k}}=\dot{\mathrm{m}}_{\mathrm{ref}} \cdot\left(\mathrm{h}_{2}-\mathrm{h}_{1}\right)$

$\mathrm{W}_{\mathrm{k}}=2.6 \mathrm{~kg} / \mathrm{s} .(404.5 \mathrm{~kJ} / \mathrm{kg}-383.7 \mathrm{~kJ} / \mathrm{kg})$

$\mathrm{W}_{\mathrm{k}}=53.4 \mathrm{~kJ} / \mathrm{s}$

\section{Kalor yang dilepaskan oleh kondensor $\left(Q_{c}\right)$}

$$
\begin{aligned}
\mathrm{Q}_{\mathrm{c}} & =\dot{\mathrm{m}}_{\text {ref }} \cdot\left(\mathrm{h}_{2}-\mathrm{h}_{3}\right) \\
& =2.6 \mathrm{~kg} / \mathrm{s} \cdot(404.5 \mathrm{~kJ} / \mathrm{kg}-167.7 \mathrm{~kJ} / \mathrm{kg}) \\
& =608.1 \mathrm{~kJ} / \mathrm{s}
\end{aligned}
$$

\section{COP (Coefficient Of Performance)}

$$
\begin{aligned}
\text { COP } & =\frac{\frac{E R}{W_{K}}=\frac{h_{1}-h_{4}}{\text { m. }\left(h_{2}-h_{1}\right)}}{383.7 \frac{\mathrm{kJ}}{\mathrm{kg}}-167.7 \frac{\mathrm{kJ}}{\mathrm{kg}}} \\
\mathrm{COP} & =\frac{\frac{\mathrm{kg}}{\mathrm{g}} \cdot\left(404.5 \frac{\mathrm{kJ}}{\mathrm{kg}}-383.7 \frac{\mathrm{kJ}}{\mathrm{kg}}\right)}{\mathrm{COP}}=4.0
\end{aligned}
$$

Dengan menggunakan rumus yang sama seperti diatas berikut diperoleh tabel hasil perhitungan data penelitian untuk keseluruhan data setelah water balancing dilakukan:

Tabel 3.5: Hasil perhitungan data setelah water balancing

\section{HASIL DAN PEMBAHASAN}

\section{Analisa Efisiensi Mesin Pendingin}

Berdasarkan rekomendasi dalam jurnal ASHRAE, suatu sistem pendingin dapat dikatakan dalam kondisi sehat (efisien) dalam operasionalnya apabila nilai COP mencapai 4 atau diatasnya.

\section{Efek Refrigerasi (ER)}

ER $\quad=\mathrm{h}_{1}-\mathrm{h}_{4}$ 


\section{ASHRAE Journal}

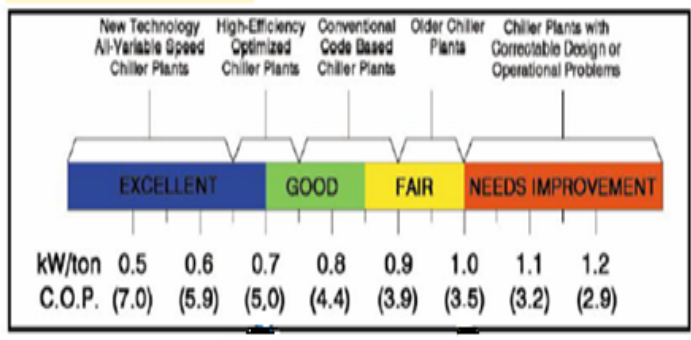

Gambar 9. Klasifikasi Efisiensi chiller berdasarkan nilai COP

\section{Analisa Data Hasil Penelitian dengan Metode Komparasi \\ Perbandingan ER dan $\mathbf{m}_{\text {ref }}$ Sebelum dan Sesudah Water Balancing}

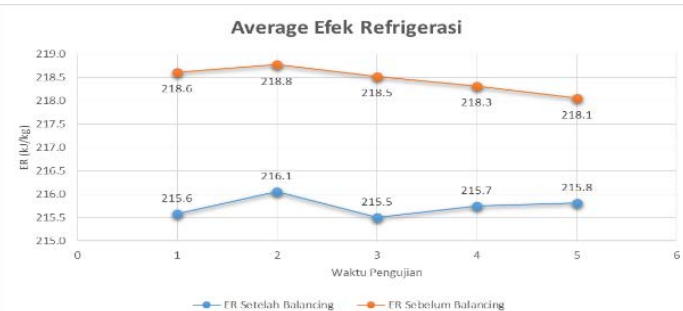

Gambar 10. Grafik rata - rata efek refrigerasi sebelum \& sesudah water balancing

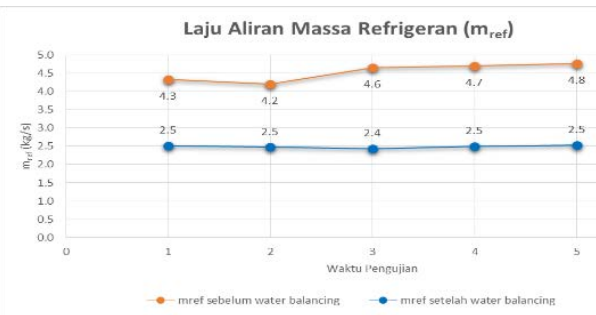

Gambar 11. Grafik laju aliran massa refrigerant sebelum \& sesudah water balancing

Berdasarkan grafik pada gambar 10. di atas, terlihat bahwa dengan adanya water balancing, efek refrigerasi yang terjadi pada sistem dapat diturunkan sebesar $2.7 \mathrm{~kJ} / \mathrm{kg}$ dari efek refrigerasi sebelum water balancing dilakukan.

Penurunan efek refrigerasi yang terjadi menyebabkan laju aliran massa refrigeran menjadi menurun seperti yang terlihat pada grafik gambar 11. Penurunan laju aliran massa refrigeran ini akan mengurangi kerja kompresi yang nantinya akan dilakukan oleh kompresor. Penurunan laju aliran massa refrigerant karena penurunan efek refrigerasi yang terjadi dalam sistem dapat mengakibatkan efisiensi mesin pendingin (COP) menjadi meningkat.

\section{Perbandingan $\mathrm{W}_{\mathrm{k}}$ Sebelum dan Sesudah Water Balancing}

Penurunan laju aliran massa refrigerant berbanding lurus dengan kerja kompresi yang dilakukan oleh sistem. Semakin kecil laju aliran massa refrigerant yang mengalir dalam sistem menyebabkan berkurangnya kerja kompresi yang dilakukan oleh sistem.

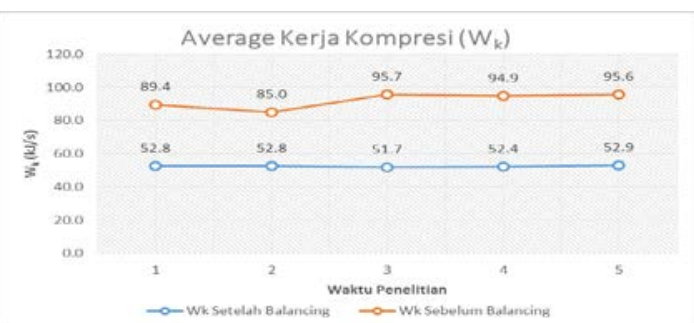

Gambar 12. Grafik rata - rata kerja kompresi sebelum \& sesudah water balancing

Berdasarkan grafik rata - rata kerja kompresi yang dilakukan oleh sistem seperti yang ditunjukkan pada gambar 12. di atas, kerja kompresi yang dilakukan oleh kompresor sebelum water balancing adalah sebesar $92.1 \mathrm{~kW}$ dan dapat berkurang sebesar $39.6 \mathrm{~kW}$ setelah water balancing dilakukan menjadi $52.5 \mathrm{~kW}$.

\section{Perbandingan Nilai COP Sebelum dan Sesudah Water Balancing}

Berdasarkan grafik nilai rata - rata COP yang diperlihatkan pada gambar 13 di bawah ini. Terlihat bahwa COP chiller system sebelum dilakukan water balancing hanya mampu mencapai nilai 2.4 atau dengan kata lain operasional chiller system tidak efisien, sesuai dengan klasifikasi efisiensi chiller system yang telah dijelaskan sebelumnya pada gambar 9. di atas.

Sedangkan dengan adanya water balancing nilai $C O P$ dapat meningkat menjadi 4.1 dan tetap stabil selama masa penelitian dan selama proses operasional seterusnya. Dengan demikian sistem pendingin telah dapat dikategorikan dalam operasional sistem yang efisien sesuai dengan jurnal ASHRAE.

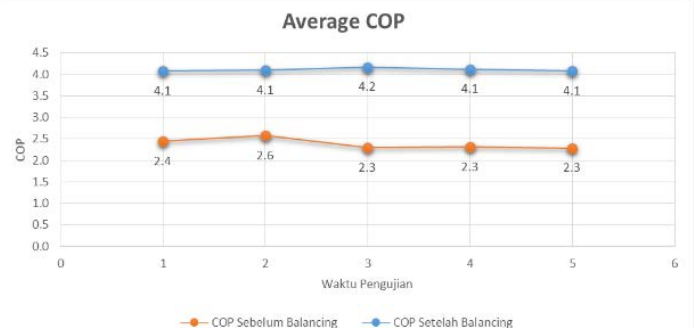

Gambar 13. Grafik rata - rata nilai COP sebelum \& sesudah water balancing 


\section{Perbandingan $\mathbf{Q}_{\mathrm{c}}$ Sebelum dan Sesudah Water Balancing}

Semakin besar kalor yang dilepaskan di kondensor akan menyebabkan temperatur air pendingin di dalam kondensor menjadi lebih cepat meningkat dalam waktu yang singkat. Tingginya suhu refrigerant yang keluar pada sisi kompresor menyebabkan entalphi keluar kompresor menjadi meningkat sehingga laju aliran massa refrigerant akan mengalami peningkatan juga. Hal inilah yang menyebabkan nilai COP sistem mengalami penurunan.

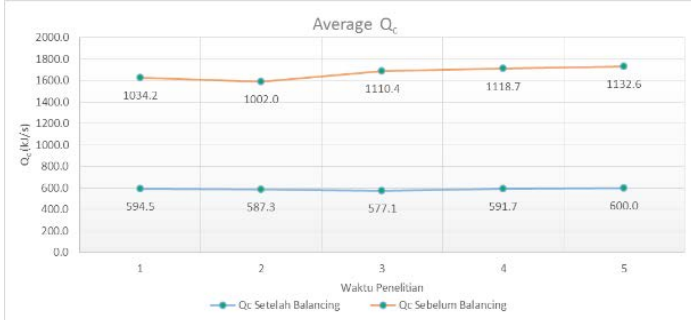

Gambar 14. Grafik rata - rata $Q_{c}$ sebelum \& sesudah water balancing

Berdasarkan grafik pada gambar 14. di atas terlihat bahwa kalor yang dilepaskan oleh refrigerant di kondensor sebelum water balancing jauh lebih besar jika dibandingkan dengan kalor yang dilepas oleh refrigerant di kondensor sesudah water balancing dilakukan adalah sebesar. Besarnya kalor yang dibuang di kondensor dapat berkurang sebesar $489.5 \mathrm{~kJ} / \mathrm{s}$.

\section{Perbandingan $Q_{e}$ Sebelum dan Sesudah Water Balancing}

Besar kecilnya laju aliran air yang masuk ke dalam evaporator juga mempengaruhi kapasitas pendinginan yang terjadi di dalam evaporator. Laju aliran air yang masuk ke dalam evaporator berbanding lurus dengan kapasitas pendinginan yang terjadi di dalam evaporator.

Semakin tinggi kapasitas pendinginan di evaporator mengakibatkan kerja kompresi menjadi meningkat, sehingga berdampak terhadap penurunan nilai COP mesin pendingin. Berdasarkan laju aliran air yang masuk kedalam evaporator yang ditunjukkan pada gambar 15. Serta besarnya beban pendinginan yang ditanggung oleh evaporator seperti yang ditunjukkan ada gambar 16. Dibawah ini, terlihat bahwa water balancing memungkinkan laju aliran air yang masuk ke dalam evaporator menjadi lebih besar sesuai dengan kebutuhan produksi yang meningkat dengan beban pendinginan yang tetap stabil dan terkontrol.

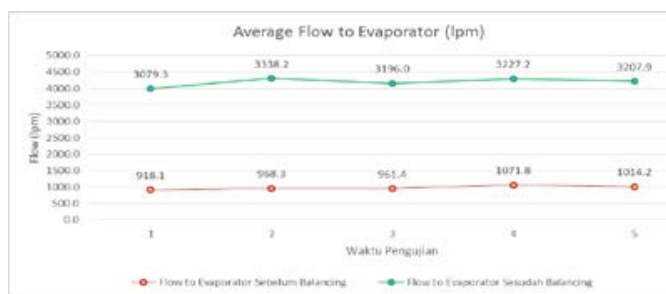

Gambar 15. Grafik rata - rata laju aliran air masuk ke Evaporator.

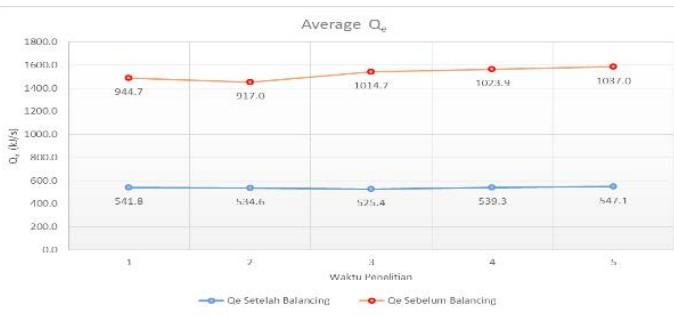

Gambar 16. Grafik rata - rata kapasitas pendinginan berdasarkan laju aliran air masuk ke evaporator.

Sebelum water balancing dilakukan, laju aliran air yang masuk ke dalam evaporator kecil dengan kapasitas pendingian yang besar. Hal ini disebabkan karena laju aliran air yang masuk kedalam sistem tidak memenuhi minimum persyaratan operasional desain yang ada, oleh karena itu temperatur chilled water yang dihasilkan tidak mampu bertahan pada range kerjanya sebelum mencapai titik pengguna akhir, sehingga besarnya penyerapan kalor yang dilakukan dalam sistem menjadi lebih besar karena media perpindahan panas yang lebih sedikit.

\section{SIMPULAN}

Berdasarkan penelitian, perhitungan serta analisis data hasil penelitian yang telah dilakukan dapat disimpulkan bahwa pemasangan water balancing terhadap sistem dapat meningkatkan efisiensi mesin pendingin yang ditunjukan dengan peningkatan nilai COP Chiller system sebagai berikut:

COP dari chilled water system mengalami peningkatan dari 2.4 (average selama 5 hari penelitian) sebelum water balancing menjadi 4.1 (average selama 5 hari penelitian) setelah water balancing dilakukan.

Kapasitas evaporator (Qe) sebelum water balancing dengan rata - rata laju aliran air masuk ke evaporator $964.6 \mathrm{lpm}\left(16.07 \times 10^{-3} \mathrm{~m}^{3} / \mathrm{s}\right)$ adalah $987.5 \mathrm{~kJ} / \mathrm{s}$. Sedangkan setelah water balancing, dengan laju aliran air yang masuk ke dalam evaporator sebesar lpm (52.70 x 10-3 m3/s) dapat diperoleh kapasitas pendinginan rata-rata 537.6 $\mathrm{kJ} / \mathrm{s}$.

Kerja kompresi (Wk) setelah water balancing mengalami penurunan sebesar $39.6 \mathrm{~kW}$ dari beban kerja kompresi sebelum water 
balancing dilakukan $(92.1 \mathrm{~kW}$ menurun menjadi $52.5 \mathrm{~kW}$ ) meskipun laju aliran air yang masuk ke dalam sistem pendingin meningkat.

Berdasarkan penjelasan kesimpulan diatas maka dapat disimpulkan bahwa untuk meningkatkan nilai COP dapat dilakukan dengan cara meningkatkan efek refrigerasi yang terjadi pada sistem serta mengurangi kerja kompresi yang dilakukan oleh kompresor dengan menurunkan laju aliran massa refrigerant dalam operasional sistem.

\section{DAFTAR PUSTAKA}

ASHRAE "Handbook Fundamental", American Society of Heating Refrigerating and Air Conditioning Engineers, Atlanta, GA. 1985.

Avery, G. "Improving the efficiency of chilled water plants”. ASHRAE Jurnal 43(5): 14-18. 2001.

D. Holder MSME, Roger. "Balancing of a Water and Air System”. ASHRAE Jurnal 37. 2003.

Durkin, Thomas H. November. "Evolving Design of Chiller Plant”. ASHRAE Jurnal 47: 11: 4050. 2005.

Gumilar, Arie. "Sistem air Pendingin". Jakarta: STE, 2011.

Herbert W. Stanford : "HVAC Water Chillers and Cooling Towers. CRC Press, $2^{\text {nd }} e d i t i o n "$, April 2016.

ITT Fluid Technology Corporation. "Large Chilled Water Systems Design Workshop Manual”. 1996.

Keister, Timothy. "Cooling Water Management Basic Principles and Technology". New York: ProChemTech International, 2008.

Shan K. Wang: "Handbook of Air Conditioning and Refrigeration, $2^{\text {nd }}$ edition”. McGraw-Hill Professional, 2001.

Stocker. W.F, Jernold. W.J., "Refrigerasi dan Pengkondisian Udara, edisi ke-2”, Erlangga, Jakarta, 1989.

Stoecker, Wilbert F., and Jones, Jerold W. "Refrigerasi dan Pengkondisian Udara". Jakarta: Erlangga, 1982. 